\title{
Effects of Advertising on Consumer Buying Behaviour: With Reference to Demand for Cosmetic Products in Bangalore, India
}

\author{
Akwasi Ampofo \\ University of Madras, Chepauk, Chennai 600005. Email: aampofoh@gmail.com
}

\begin{abstract}
The study seeks to examine the effects of advertising on consumer buying behaviour considering demand for cosmetic products by residents in and around Nagarabhavi, Bangalore. Using a sample of 100 respondents of mostly the young, we ran regressions and found that advertising does influence expenses incurred on cosmetics products but much influence on the purchase of cosmetic products results from one's income or pocket money available, and other factors like price of the product, the brand and other people's recommendation concerning the product.

We concluded that, advertising satisfies the needs of the firm and the wishes of consumers. Its role cannot be replaced by any other means. Therefore firms must strategize and know when and where they should advertise. The consumers need to be informed about products and until that is done, the products of firms will still be in stores with no demand for them.
\end{abstract}

JEL Classification: M37, D12

Keywords: Advertising--impact, Consumer behaviour--Bangalore, Cosmetic products—demand, Cosmetics demand-Bangalore

\subsection{Introduction}

Consumers are final end user of products. They keep the production cycle moving. Consumers do play a vital role in the economic system of any nation, thus, any nation will face crisis if consumers don't have the effective demand for goods produced.

Consumers demand different commodities based on their taste and preference for them. Awareness of good influences consumers purchase of that good. Other factors that influence one's taste and preference for a good are psychological and environmental. Taste and preference for a good change overtime. Awareness of a product, thus, advertisements, play a role in influencing the taste and preference of consumers' choice.

Consumers are known to be rational with regard to their purchases, wanting to maximize their satisfaction when it comes to consumer goods. A consumer will therefore not purchase a commodity whose price is above the additional satisfaction that he derives from the good. How much of a good demanded, depends on the satisfaction the consumer gains from spending extra money on the good. Rational consumers will spend on a good till their gains equal the cost they pay for the product. Thus where $\mathrm{MU}_{\mathrm{P}}=M \mathrm{C}_{\mathrm{P}}$ (Sloman and Wride, 2007)

Advertising is the mass publicity of a product. It involves creating awareness of a product's uses and benefits to others. Doing this makes a product available to those in need of them and this satisfies the needs of the advertiser; increasing sales.

According to Cohen, advertising is a business activity that employs creative techniques to design persuasive communication in mass media that promote ideas, goods, and services in a manner consistent with the achievement of the advertiser's objective, the delivery of consumer satisfaction and the development of social and economic welfare. (Cohen, 1988)

From Cohen's definition, it can be found that advertising satisfies 3 objectives; to increase sales of the firms, to guarantee consumers a great deal of service and finally to ensure the social and economic welfare of society.

Advertising is seen in various ways. One encounters them mostly while watching television, reading magazines and newspapers, surfing the internet, and on the radio or even simply while walking down the street (Sharma and Sharma, 2009). Advertising has thus, a stimulating influence on the purchasing behaviour of the consumers.

Advertising are most effective on products that have intrinsic qualities. These qualities are not known at the time of purchase and it takes one to discover this upon using the product. Also, when there is a substantial chance of differentiating a product, it best suits to advertise on that product. Again, when there is a strong emotional purchasing motive such as to protect health or enhance social position, it pays to advertise on such a product. These conditions make the demand for the product more inelastic. The more emotions consumer attach to a product, they more they tend to be insensitive to its price. This is of importance to firms as they can earn high sales in pricing their products (Borden, 1942).

Advertising on food, clothing, durables and household items tend not to yield higher sales. Consumers are not affected much by the publicity on such items as they consume such products on a daily basis. The higher the consumption of a product, the less effective is advertising on them. Advertising thus tend to have a less marginal effect on such items (P. Doyle, Nov., 1968)

Advertising has a long term dynamic effect on consumers' purchase and sales of producers. A firm's reason for 
advertising is to create awareness of a product. This has effect on current and future sales of firms as consumers tend to respond to the advertisement in the long run. This dynamic effect of advertising explains that firms usually advertise a product the most at the entry. (Sharma and Sharma, 2009)

Producers often advertise their product with the intention of increasing their sales which allows the firms to gain economies of scale and keep prices down. It also makes their products well known on the market. Also, advertising is necessary when introducing new products on the market. Without it, firms would find it difficult to break into market in which there are established brands.(Sloman and Wride, 2007)

Advertising increases output, but increased output in turn increases production cost and this must be taken into consideration when comparing the cost and benefit of extra money of advertisement. The correct decision is to increase advertising until the marginal revenue from an additional money from advertisement, is just equal to the full marginal cost of that advertisement. That full marginal cost is the sum of the money spent directly on the advertisement and the marginal production cost that results from the increased sales that advertisement brings about. Thus the firm should advertise where $\mathrm{MR}_{\mathrm{A}}=\mathrm{MC}_{\mathrm{A}}$. (Pindyck and Rubinfield, 1995)

Indian consumer market is one of the fastest growing markets in the world with a very high increase in the demand for luxury goods and personal care products. According to reports by Beauty Mart, the personal care products specifically, the beauty industry in India, is growing at a rate twice that of the US and Europe. The cosmetics market alone is growing about $15 \%$ to $20 \%$ annually, making it the right place for investors to channel their resources. The cosmetic products market have seen a $60 \%$ growth over the past five years. (Beauty Mart, 2013)

The quest of this research was to find if this massive growth in the cosmetic market is as a results of the advertisement made on the cosmetic products or other factors.

As stated previously, advertising affect products that are believed to have an intrinsic quality that is not known at the time of purchase. One of such products is cosmetics. It isfor this reason that we have chosen this product as a case study.

\subsection{Statement of the problem}

Advertising is essentially to fulfil the traditional desire of firms to reach the ever increasing population so that their products may receive optimum exposure. The role of advertisement; to increase sales revenue and profits of the local firms and increase the demand for goods, has been falling apart. (Sundarsan, 2007). Most increase in product sales, especially, cosmetic products have been attributed to other factors like taste; long term use of a product and users unwillingness to switch products. This has raised numerous questions as to why cosmetic firms still do advertise their products.

Advertising has been a subject for debate either on one pretext or another for decades at the beginning of the 19th century. People showed little interest but it later became a fertile topic for research at the turn of the 19th century. (Sharma and Sharma, 2009).

This study therefore seeks to find out the role advertising play in the consumer buying behaviour of cosmetic products with emphasis to its users in and around Nagarabhavi, Bangalore.

We are considering cosmetic product because we believe it satisfies the conditions of commodities on which it is effective to advertise. There are a lot of cosmetic products which are differentiated but serve the same purpose. Again these products are believed to have intrinsic qualities which can only be known after it has been used and lastly, some consumers attach strong emotions to the end products of these good and use it to improve their social status.

\subsection{Objectives}

The general objective of the study was to find out if there is any effect of advertising on consumer buying behaviour of cosmetic products in Bangalore.

In our quest to achieve the general objective, the following specific objectives were set and formulated to guide in data collection and analysis:

i. To know the extent to which purchases of consumers are based on advertisement.

ii. To find the age and social group that is influenced by advertised cosmetic products.

iii. To find out the motives and reasons of consumers for demanding advertised cosmetic products.

iv. To know the other factors influencing consumer purchase besides advertisements

The study continued with review of literature on advertising and the consumer buying behaviour. It then followed with the methodology employed in the study. The findings and results were then presented which was followed by conclusion and recommendations for cosmetic firms.

\subsection{Literature Review}

In reviewing previous works on the subject matter, so many views cropped up with others adding new knowledge to the subject.

2.1 Issue of Advertising in Economics: The Overview

Advertising has been a subject discussed over centuries ago, but prior to the $20^{\text {th }}$ Century, this subject was not as 
important as it seems now. The reason been that, in the $19^{\text {th }}$ century, economist were busy trying to develop the theory of perfect competitive markets, this theory assumed that, there was perfect information in the market and that, consumers had fixed preference for their products which were homogenous in nature. It was then thought of as a waste of resource and an increase in cost of production for one to advertise on products because consumers were not in any way going to respond to that. (Bagwell, 2001)

Also, there was no large scale production until the late $19^{\text {th }}$ century when numerous inventions cropped up. The advancement in transportation and technology, made producers rethink their decision to improve their capacity and thus, ensure publicity of their products. (Bagwell, 2011)

After these happenings, advertising then became an important area for economist to research into. An early reflection was given by Alfred Marshall (1890, 1919). In his works, "Principles of Economics" and "Industry and Trade". He marks out two roles played by advertising. To him, advertising might be useful in providing information to consumers which will help them satisfy their wants. He termed this as a constructive role played by advertising. The second role he calls a combative role played by advertising may provide less information to consumers leading them to shift among products. Marshall gave an insight to the role of advertising but less can be said of its fusion to microeconomics. (Bagwell, 2011)

Chamberlin in his work "The Theory of Monopolistic Competition" came up with new ways of looking at advertising. He modelled the expenditure of a firm as a "selling cost" that expands a firm's demand for a differentiated product. In his work, he describes a market structure in which there are many firms producing and selling similar but not identical products. In this market, Chamberlin believes that advertising may provide consumers with information about their wants but also adds that, it can be persuasive and alter one's demand for another. Advertising when informative makes consumers responsive to price changes and thus increases the demand elasticity for the product but a persuasive advert will create brand loyalty making the demand for a good inelastic(Bagwell, 2011).

Scale economies play a central role in Chamberlin's work and he believes that, such economies may exist in production and advertising as well.

Chamberlin then concluded that, the effects of advertising cannot be determined by theory alone, thus where a firm's demand curve is tangential to its U-shaped average cost of production and selling, but by also considering the extent to which advertising is whether informative or persuasive and also whether scale economies exist. (Bagwell, 2011)

After this insight by Chamberlin, there came into existence three views of advertising; persuasive, informative and complementary.

The persuasive view developed by Robinson and later advanced by Braithwaite (1928) and Kaldor (1950), and empirically supported by Bain (1956) and Comanor and Wilson (1967) holds that, advertising affects one's demand and it is capable of ensuring brand loyalty. This view adds that, advertising makes demand for a product inelastic and thus ensures increase in the price of the product and this effect might lessen as a result of scale economies. The view also adds that, consumers are unwilling to try new products especially those of unknown quality and this may deter entry of new producers. These scholars agree that, this view of advertising will only work in the presence of scale economies in production.

The informative view of advertising, propagated by Ozga (1960) and Stigler (1961) holds that, advertising serve to inform consumers about a product. They add that, advertising increases the demand elasticity for a product and this happens because, it is believe by these scholars that, as information of a product is given, it is assumed the product is of high quality and this can even increase the demand for products which is of low quality in general.

There is the complementary view of advertising which is developed by Stigler and Becker (1977) and thoroughly defended by Stigler and Murphy (1989). This view believes that, advertising influences consumers by attaching a "complementary influence in the consumer's utility function" (Bagwell 2001). It might be that, a consumer would like to attain some status in society and using a certain product is capable of achieving this. What this view means is that, the consumer, in his quest to achieve this social status will be influenced by this advertising. These views make us understand the different phases through which advertising has gone and we now know the areas through which advertising works perfectly.

2.2 Advertising and Consumer Behaviour

A firm's primary mission is to reach prospective customers and influence their awareness, attitudes and buying behaviour. They spend a lot of money to keep individuals (markets) interested in their products. To succeed, they need to understand what makes potential customers behave the way they do. The firm's goal is to get enough relevant market data to develop accurate profiles of buyers to find the common group for communications. This involves the study of consumer behaviour (Arens, 1996).

Proctor et al. (1982) noted that the principal aim of consumer behaviour analysis is to explain why consumers act in particular way under certain circumstances. The study tries to determine the factors that influence consumer behaviour, especially the economic, social and psychological aspects which can indicate the most favoured 
marketing mix that management should select.

Consumer behaviour analysis helps to determine the direction that a consumer's behaviour is likely to take and to give preferred trends in product development, attributes of the alternative communication method etc.

Consumer behaviour analysis views the consumer as another factor of production, a factor that producers cannot control and this factor interprets the product or service not only in physical terms, but also according to their social and psychological makeup.

Incorporation of this knowledge in any firm's decision will ensure a greater satisfaction of the firm's objective. Most views have cropped up as to maintaining a sustained profit and it is when firms adopt to the new order of making consumers a part of their daily decision, other than just selling products to them, will firms achieve this target. Firms in achieving this state have a greater gain in advertising their products.

\subsection{The Indian Buying Behaviour}

The Indian consumer buying behaviour has seen tremendous growth over the past years. This can be attributed to the high growth in the middle class in the country. This increase in the middle class has resulted in increased demand for luxury and personal care products. Many foreign firms and entrepreneurs have noted the increase in the demand for goods and have ensured increasing supply of these goods to consumers. A lot of foreign companies moved into the Indian market after the liberalisation of trade and there have been massive increase in job opportunities and income resulting in high demand for goods and services.

The rise of companies after trade and liberalisation in the $1990 \mathrm{~s}$, saw most cosmetic firms enter India with local ones gaining grounds from partnerships. Consumers have since then increase their demand for products of these cosmetic firms. It is in this steady growth that the Associated Chambers of Commerce and Industry in India, ASSOCHAM (2013) estimated the Indian cosmetic market to be $\$ 50$ billion. The high demand in cosmetic products has been a great deal for firms and the Indian market has also benefitted from the products provided by these firms.

ASSOCHAM has also found out that, there is increase in the buying behaviour among the youth in India especially with regard to personal care products. They attributed the increase in the female spending on cosmetic products to an increase in female employability and females being bread winners in their families. They also found out that, men on average spend more on cosmetic products than women, with the men spending averagely about Rs.1000 - Rs.5000 on cosmetic products monthly. This, they attributed to men's demand for decent hair care, deodorants and razor blades. The high increase in the spending on cosmetic products is as a result of the youth in India being conscious of their bodies and looking for products to enhance their physical appearance. With an increase in the level of literacy and the influence of the media, there has been a greater influence on the spending of males in particular (ASSOCHAM, 2013)

This high growth in demand for cosmetic products makes it worthwhile researching this area to know the motives behind consumers purchase and factors associated with their purchase.

2.4 Empirical Review

Finding the relationship between advertising and buying behaviour empirically, Ekelund and Gramm (1969) in studying “A Reconsideration of Advertising Expenditures, Aggregate Demand and Stabilization" concluded that, there is no positive relationship between advertising and aggregate consumption.

Taylor and Weiserbs (1972) in studying the relationship between advertising expenditure and aggregate consumption using Houtakker-Taylor model revealed that, there is a simultaneous relationship between advertising and consumption but not a unidirectional. Thus, advertising and consumption seem to work on each other.

Dr. Abey P. Philip (2007) in his study of "The Relationship between Advertising and Consumption in India: An Analysis of Causality" made use of unit root test, cointegration and error correction model and found out that, fluctuations in advertising expenditure positively impacts consumption expenditure.

Sharma and Sharma (2009), using Fixed Effect Model of Panel Data Analysis for 134 companies, found in their study that, besides advertising, factors like company's brand, quality of the product and company's reputation affect the sales of a company.

Dr. Naveen Kumar et al. (2011), using mean and standard deviation, in their study of advertising and consumer buying behaviour with special reference to Nestle Limited, India found that, advertising and sales promotion together with the image of a company influence the consumer buying decision. They added that, the quality and price of a product also influences a consumer's purchase of a good.

Banerjee et al (2012) found evidence of cointegration between marketing communication and sales in the personal care industry in India.

Bin Junaid A. et al (2013) found in their study of female buying behaviour of cosmetic products in New Delhi and NCR that, as income of females increase, their purchase of cosmetic products also increase. They also, added that, this increase in expenses on cosmetic product is made possible by the advertisement made on them. ASSOCHAM (2013) in a survey of 2000 youth in major cities in India found that, there is a high increase in the consumption of cosmetic goods among the youth. They added that, men on average spend more on cosmetic 
products than their female counterparts and attributed this increase to the awareness created on the products. 2.5 Research Gap

From literatures reviewed, we can say that, indeed advertising has a positive effect on the purchase of consumers and it positively influences the sales of companies.

We found that most work done in the subject, found out the effects of advertising on companies' sales using various econometric tools. Little can be said of work done on the consumers' side using econometric analysis.

Also, most reviewed literature made use of descriptive statistics thus, measures of central tendency and dispersion which didn't give any empirical evidence as to how much effects advertising has on consumer buying behaviour. It is therefore a necessity to have this research done.

\subsection{Methodology}

The study was to find the effects of advertising on consumer buying behaviour of young men and women with a special case of users of cosmetic products in and around Nagarabhavi, Bangalore.

The methodology used to help us with the research, shows how the research was carried out taking into consideration available resources and limitations.

3.1 Study Area

The study area for the research was Bangalore, which is the capital city of Karnataka State. It is in the Southern part of India. Most respondents were people in and around Nagarabhavi, which is a suburb of Bangalore.

3.2 Sample Size

The sample size for the study was 100 youth respondents who reside in and around Nagarabhavi, Bangalore. From previous studies it is revealed that most consumers of cosmetic products are young men and women in India (ASSOCHAM, 2013) and based on this revelation, we selected this group to have our objective achieved.

3.3 Sampling Technique

The sample techniques selected in administering the questionnaire were purposive sampling, and snowball sampling. Purposive sampling was used considering mostly the youth in the area as found in previous studies, the snowball sampling was used to get easy access to cosmetic product users and ensured faster gathering of information.

This sample was chosen bearing in mind the constraints and the limited resources. Using the snowball sampling technique, an online questionnaire, created with Google Forms was administered to some people in and around Nagarabhavi. This was to get responses from mostly females. It was difficult for males and especially a foreigner to have females respond to the questionnaire.

3.4 Source and Type of Data

The sources of data were primary data, collected from respondents in the study area, observations and interviews conducted with respondents and sales managers.

There were unstructured interview with sale managers of cosmetic products at 2 different malls in and around Nagarabhavi, Bangalore. We found out from the managers, how consumers reacted to goods advertised, factors they considered before making purchase and the reasons behind their purchase of these goods.

Sales managers also gave us information on the brands most patronised by consumers of cosmetic products. They also gave us the proportion of brands that make up most of their monthly sales.

Observations of the consumers were made at these two Malls as they purchased cosmetic products. We interacted with them when they were done filling the questionnaire.

The information collected through the issued questionnaire, interviews and observation gave us a clear understanding of the buying behaviour of the youth on cosmetic products and which factors they considered in their purchase.

3.5 Research instrument

Questionnaire was the main device used in the collection of data. Primary data were used. Primary data are the pieces of information elicited from respondents which were directly related to the research topic.

The questionnaires contained structured questions with the main aim of eliciting information on the effects of advertising on consumer's purchase. The questionnaire was structured with closed ended questions and open ended questions. The closed ended questions made it easier to compare the views of the respondents. It also provided standardized responses and made coding easy. The open ended questions gave the respondents more room to express their views and opinions, answer questions in their own way and give suggestions where necessary. It also gave us different views from the respondents and quantitative information on the monthly income or pocket money and expenses made on cosmetics. Using the data from the consumers assisted us to process the information needed and to test the information empirically.

The questionnaires were made up of list of questions relating to the objectives of the study. The questionnaire was made up of two sections; demographic data and those relating to the study. Each of these sections focused on specific issues that relate to the research question. The questionnaires were administered with greater assurance of confidentiality, anonymity and convenience. 


\subsection{Data Collating/Processing}

The collected data was then collated and analysed using SPSS and STATA. These are statistical package tools used for presenting and analysing data. Using SPSS, we found the descriptive statistics of the data and presented them in graphs. We cross tabulated some variables like age and sex, advertising effect and sex among others. This was to find out which group had advertising influencing their purchase of cosmetic products.

Using STATA, we ran a regression of expenses on cosmetic products on income of consumers, advertising, price, brand, and recommendation influence on consumers.

Using qualitative data made it easier to know and observe the behaviour of consumers of cosmetic products. To achieve our objectives, this data helped us know which among the social groups are influenced most by advertising in their purchase of cosmetic products and also to what extent their purchases are affected by adverts as well. Also, the data gave us most of the qualities consumers look out for before making purchases like the price, income and others recommendation.

3.7 Regression Model

The regression model that was ran using STATA was

$E X P=\beta_{1}+\beta 2$ ln_INCOME $+\beta_{3} D a+\beta_{4} D b+\beta_{5} D p+\beta_{6} D r+\varepsilon$

Where $E X P=$ Expenses on cosmetic products and which is the dependent variable.

In INCOME is the log of income of consumers, which is the covariate of the model

$D \bar{a}$ is the dummy for those influenced by advertising.

$D a=1$, when respondents are influenced by advertising, $D a=0$, if otherwise

$D b$ is the dummy for those considering the brand of cosmetic products.

$D b=1$ when one considers brand of cosmetics products, $D b=0$, if otherwise

$D p$ is the dummy for those considering the price of a cosmetic product.

$D p=1$ when one considers price, $D p=0$, if otherwise.

$D r$ is the dummy for those influenced by others recommendation in their purchase.

$D r=1$, when one considers others' recommendation, $D r=0$, if otherwise.

$\beta_{I}$ is the intercept or benchmark for those who aren't influenced by advertising, price, brand and recommendation from others in their purchase.

$\beta_{2}$ is the slope coefficient of income showing the absolute change in income on expenses made.

$\beta_{3}, \beta_{4}, \beta_{5}, \beta_{6}$ are the differential intercept coefficients of those influenced by advertising, brand, price and other's recommendation.

$\sum$ is the error term factoring other factors that affects the purchase of cosmetic products but are not considered in the model

The log of income or pocket money was used to correct any biasness in the data and make it easier to explain and understand.

It would have been appropriate to estimate the price elasticity for cosmetic products, however it was not possible to include the actual prices in the model since information on that was not provided for in the questionnaire hence introducing a dummy for how price influences customers' purchase was the best option. This was because, consumers purchase different products even within the same brand, hence using the prices of different products would be difficult for the study.

The dummies were used to know how consumers rate these factors before making a purchase. Since the study is on consumers' behaviour in purchasing cosmetic goods, factoring these qualitative variables was essential.

3.8 Hypothesis testing

The hypotheses of the regression model were then tested to know empirically, the effects of advertising on consumer purchase of cosmetic products. Other variables in the model were also tested. The null and alternate hypotheses formed were;

$\mathrm{H}_{\mathrm{o}}$ : advertising has no influence on the consumer's purchase of cosmetic products

$\mathrm{H}_{1}$ : advertising has influence on the consumer's purchase of cosmetic products

$\mathrm{H}_{\mathrm{o}}$ : income of consumers has no influence on the consumer's purchase of cosmetic products.

$\mathrm{H}_{1}$ : income of consumers has influence on the consumer's purchase of cosmetic products.

$\mathrm{H}_{\mathrm{o}}$ : price of a product has no influence on the consumer's purchase of cosmetic products

$\mathrm{H}_{1}$ : price of a product has influence on the consumer's purchase of cosmetic products

$\mathrm{H}_{\mathrm{o}}$ : Others' recommendation has no influence on the consumer's purchase of cosmetic products

$\mathrm{H}_{1}$ : other's recommendation has influence on the consumer's purchase of cosmetic products

$\mathrm{H}_{\mathrm{o}}$ : Cosmetic brand has no influence on the consumer's purchase of cosmetic products

$\mathrm{H}_{1}$ : Cosmetic brand has influence on the consumer's purchase of cosmetic products

\subsection{Data Findings and Analysis}

After collating the questionnaires administered and the observation and interview conducted, the following were the findings. 


\subsection{Observation and Interview.}

Table1.0

\begin{tabular}{|c|c|c|c|c|}
\hline & \multicolumn{2}{|c|}{ Consumers } & \multirow[t]{2}{*}{ Sales Managers } & \multirow[t]{2}{*}{ Total } \\
\hline & Men & Women & & \\
\hline $\begin{array}{l}\text { Total Number of } \\
\text { Observation }\end{array}$ & 10 & 15 & - & 25 \\
\hline $\begin{array}{l}\text { Total no of Interviews } \\
\text { conducted }\end{array}$ & 8 & 10 & 2 & 20 \\
\hline
\end{tabular}

From 25 observations on consumers, we came to understand that, men and women go in for cosmetic products for various reasons and are influenced by advertising through various means.

We observed and interacted with 10 females who use cosmetic products and they stated that their reason for using them were to be confident and elegant. According to them, the mere thought of other's recognising their physical looks boost their morale and makes them give their best. They added that, they are loyal to a brand of cosmetic product they have been introduced to it by their family, particularly their mothers and do not consider changing those brands for any other, irrespective of the adverts made on those products. Some are price sensitive to cosmetic products and do not consider any brand or adverts made on them that much. Thus, they purchase the products that is within their budget. Others also added that, they depended on the recommendation from others. They believed that, the words from their friends about a product really is worth purchasing.

Advertisements on cosmetic products, according to these women, inform them on the essence of using the product and create awareness of the cosmetic products but their purchase of these products is highly influenced by other factors like the quality, brand, others recommendation and price.

Interaction with 2 other females after they are done filling the questionnaire revealed that, they were emotionally attached to the Oriflame brand. Their reason was that, the adverts on the products claimed, the final products are not tested on animals, and to these women, this appeals to them making them patronise the product.

8 men we interacted with were mostly concern about how they wanted to be seen among their peers. Most of these who were single wanted to appear presentable. Most men like to go with a brand they are familiar with, depending mostly on recommendations from their friends even when they have seen an advert of the product on television and the internet. Some men, like the women, were price sensitive; they considered the price at times when purchasing a product.

Some respondents also added that, they admire celebrities promoting cosmetic products. They believe, the mere fact that a 'Superstar' was using the product means, it is of value and worth purchasing. This in a way influences their purchase of the cosmetic products. These celebrities create a certain level of brand loyalty for consumers and some are unwilling to switch brands irrespective of the adverts they see of other products.

From our interaction with two (2) sales managers of cosmetic products at Gopalan Arcade and Garuda Mall all in Bangalore, they revealed that, most customers come with a particular product brand in mind. They purchase those products and do not consider any other. Others also come describing an advert they saw on television. These adverts are mostly of celebrities associating with a brand. Most customers however, were price sensitive and compared prices to know which product is cheaper and of good quality. Some of these customers, the managers added, rely sometimes on the recommendation of sales attendants and the managers themselves.

The managers also revealed that, most female costumers patronise brands like Lakmé from Hindustan Unilever Limited, Revlon and Nivea. They added that, these brands make up most of their sales every month. According to them, they have promotional sales in arrival of new products on the market and the reception they get is always overwhelming.

With the men, the managers revealed that, they patronise products like Garnier and L'Oreal. Some men, according to the managers, use unisex products from Lakmé as well.

Attempts made to contact the Head of Sales Department at Hindustan Unilever Limited were unsuccessful after numerous emails sent and calls made. This was to find out how the company monitor its advertisement on cosmetic products and how they evaluate the impact of advertisement made on their cosmetic products.

\subsection{Findings from Questionnaire}

The 100 questionnaires were administered and various responses were gathered and processed.

4.2.1 Income and expenditure distribution of respondents

From the data gathered, males made up 50\% with females taking the other 50\%. Men spent on average, $4.26 \%$ of their monthly pocket money on cosmetic products, while the females spend $4.78 \%$.

One remarkable thing noticed in the table is that, the standard deviations of income is more than the mean value. This is as a result of the high outliers in the income with the minimum being Rs. 1,000 and highest being Rs. 100,000.It can also be seen that, most respondents recorded Rs. 5,000 as their monthly pocket money. This can be attributed to most of the respondents being students and having below the mean value as pocket money. 
Table II.

\section{Descriptive Statistics}

\begin{tabular}{|l|r|r|r|r|r|r|}
\hline & \multicolumn{2}{|c|}{ Men } & \multicolumn{2}{c|}{ Women } & \multicolumn{2}{c|}{ Total } \\
\hline & \multicolumn{1}{|c|}{ Income } & \multicolumn{1}{c|}{ Expenses } & \multicolumn{1}{c|}{ Income } & \multicolumn{1}{c|}{ Expenses } & \multicolumn{1}{c|}{ Income } & \multicolumn{1}{c|}{ Expenses } \\
\hline Total no. obs & 50 & 50 & 50 & 50 & 100 & 100 \\
\hline Mean(Rs.) & 15596 & 665 & 14682 & 702 & 15139 & 683.5 \\
\hline Median(Rs.) & 10500 & 500 & 5000 & 500 & 10000 & 500 \\
\hline Mode (Rs.) & 10000 & 1000 & 5000 & 500 & 5000 & 500 \\
\hline Standard Dev. & 16844.5 & 482.7906 & 17812.84 & 494.3518 & 17253.77 & 486.4846 \\
\hline Minimum(Rs.) & 1500 & 100 & 1000 & 100 & 1000 & 100 \\
\hline Maximum(Rs.) & 100000 & 2000 & 80000 & 2000 & 100000 & 2000 \\
\hline
\end{tabular}

4.2.2 Advertising influence on cosmetic products

Out of $39 \%$ preferences for Hindustan Unilever products, $29 \%$ of the respondents are influenced by advertising when making purchase. $15 \%$ out of $20 \%$ of users of the Garnier brand are influenced by advertising in their purchase. Nivea has $11 \%$ out of $17 \%$ of users, being influenced by advertising. In all, $70 \%$ of the responses have advertising influencing their purchase of cosmetic products. This percentage is highly remarkable as firms get returns for investment made in publicising their products. Surprisingly, the same number of men and women are influenced by advertising on cosmetic products. From the study, 35\% of males and $35 \%$ of females have advertising influencing their purchase of cosmetic product, representing $70 \%$ of total sample surveyed.

Advertising influence reach a lot of people through different media. Out of the $70 \%$ of respondents influenced by advertising, $48 \%$ encounter advertising messages on television, $14 \%$ from the internet and $8 \%$ through the print media. Effective use of these media will ensure increase in the sales revenue of firms.

When we consider the age group of the respondents, advertising has a stronger influence on the purchase of the working group; those within the range of 25-35 years. Thus, 50\% of respondents who are influenced by advertising fall in this group, with $48.6 \%$ from the age range $15-25$ years. This shows that, most people in the working group are responsible for most purchase of cosmetic products. But it should also be noted that, those within the age range 15-25 years should also be factored in the manufacturing of cosmetic products and advertising on them.

As to whether the respondents were satisfied using the product they purchased or not, $61 \%$ out of the $70 \%$ of those influenced by advertising on a cosmetic products asserted that, they were satisfied with them with the remaining $9 \%$ not satisfied using the product. Most of those who were satisfied after using the product added that, their expectations on the products were met and the advertising did really inform them about the product. The remaining 9\% who were not satisfied after purchasing the product via the adverts on them added that, the advertisement exaggerated and the products did not meet their expectations as was informed via the adverts. This affirms Marshall and Chamberlin's view on the roles of advertising as being constructive and combative.

4.2.3 Regression Output

Several regression models were ran to know the best functional form in relation to our study. The most appropriate functional form we got was the lin-log model, with the expenses on cosmetic product being the dependent variable and the log of income or pocket money together with other qualitative variables being the independent variables. In estimating this, the following regression was ran using STATA.

$E X P=\beta_{1}+\beta 2 \ln I N C O M E+\beta_{3} D a+\beta_{4} D b+\beta_{5} D p+\beta_{6} D r+\varepsilon$

After running the regression, upon checks, we realised that, there existed unequal variance thereby resulting in the insignificance of income.

The Cook-Weisberg test for heteroskedasticity was conducted and it revealed that, the chi-square test for the residuals was 8.24 with a p-value of 0.0041 , which means rejecting the null Hypothesis, thus, variance is constant. To correct this error so as to make the model

BLUE, we ran a robust regression and the outcome showed that, the test statistic for income was now significant at $5 \%$. 
Output 4.1

- reg Expense Inincome Da Db DP Dr

\begin{tabular}{r|crc} 
Source & SS & df & MS \\
\hline Model & 4774816.42 & 5 & 954963.285 \\
Residual & 18655458.6 & 94 & 198462.325 \\
\hline Total & 23430275 & 99 & 236669.444
\end{tabular}

Number of obs $=\quad 100$

$F(5,94)=4.81$

Prob $>\mathrm{F}=0.0006$

R-squared $=0.2038$

Adj R-squared $=0.1614$

Root MSE $\quad=\quad 445.49$

\begin{tabular}{r|rrrrrr}
\hline Expense & Coef. & Std. Err. & $t$ & P > t I & [95\% Conf. Interval] \\
\hline Inincome & 77.12331 & 41.99456 & 1.84 & 0.069 & -6.257877 & 160.5045 \\
Da & 409.7348 & 117.7648 & 3.48 & 0.001 & 175.9099 & 643.5596 \\
Db & -118.1303 & 217.0312 & -0.54 & 0.588 & -549.0509 & 312.7904 \\
Dp & 205.5358 & 137.7003 & 1.49 & 0.139 & -67.87151 & 478.943 \\
Dr & 224.1852 & 111.7674 & 2.01 & 0.048 & 2.268537 & 446.1019 \\
_cons & -592.2451 & $\mathbf{4 4 4 . 6 1 3 5}$ & -1.33 & 0.186 & -1475.036 & 290.5453 \\
\hline
\end{tabular}

\section{Output 4.2}

Test of heteroskedasticity

- hettest resid

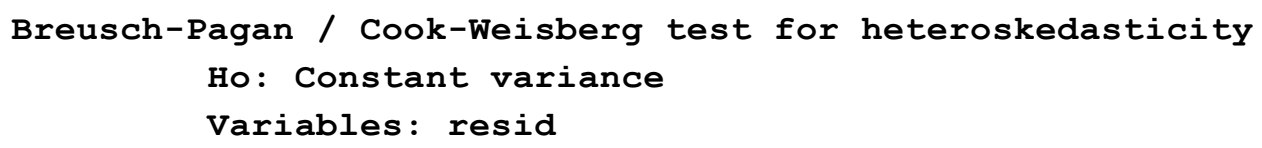

\section{Output 4.3}

Linear regression

$\begin{array}{llr}\text { Number of obs } & & 100 \\ \text { F( 5, 94) } & =7.43 \\ \text { Prob > F } & =0.0000 \\ \text { R-squared } & =0.2038 \\ \text { Root MSE } & =445.49\end{array}$

\begin{tabular}{r|rrrrrr}
\hline & \multicolumn{7}{|c}{ Robust } \\
Expense & Coef. & Std. Err. & $t$ & P>|t] & [95\% Conf. Interval] \\
\hline Inincome & 77.12331 & 38.35454 & 2.01 & 0.047 & .9694786 & 153.2771 \\
Da & 409.7348 & 82.48144 & 4.97 & 0.000 & 245.9659 & 573.5036 \\
Dp & 205.5358 & 114.3759 & 1.80 & 0.076 & -21.5603 & 432.6318 \\
Db & -118.1303 & 111.9414 & -1.06 & 0.294 & -340.3926 & 104.1321 \\
Dr & 224.1852 & 103.7664 & 2.16 & 0.033 & 18.15466 & 430.2158 \\
_cons & -592.2451 & 373.8965 & -1.58 & 0.117 & -1334.625 & 150.1351 \\
\hline
\end{tabular}

Fitting the regression showed that, a consumer's income was positively related to the expenses made on cosmetic products. The slope coefficient of income means that, an increase in income by $1 \%$ will increase the expenses on cosmetic products by Rs. $0.77\left(\beta_{2} * 0.01\right)$. This shows that a consumer will increase his or her expenses on cosmetic products by Rs. $0.5\left(\beta_{2} * \frac{1}{\text { mean of income }}\right)$ for a Rs. 100 increase in income. This shows a relatively smaller increase in expenses on cosmetic products for a larger increase in income. Thus a $1 \%$ change in income will increase expenditure on cosmetic products by $0.11 \%$. Notwithstanding this, the slope coefficient of income was statistically significant at 5\% and it therefore plays an important role when one considers spending on cosmetic products. 
Advertising influence has a positive effect on expenses made on cosmetic products. One who is influenced by advertising will spend on average, Rs. 409.73 more on cosmetic products than those not influenced by it. This shows a greater influence of advertising on the purchase of cosmetic products as indicated by $70 \%$ of the respondents who purchase cosmetic products. The coefficient of advertising influence is statistically significant at $5 \%$ indicating the important role advertising plays on the purchase of cosmetic products.

The recommendation from others also positively influence the expenses on cosmetic products. One who follows the advice of others spend Rs.224.19 more than those who do not. Statistically, this coefficient is significant at $5 \%$ and shows that, what other people say of a product positively influences the expenditure made on it.

The influence of price has positive effect on how much is spent on cosmetic products. This shows that, someone who is cautious of price differences will spend Rs.205.04 on cosmetic products. This coefficient is not statistically significant at $5 \%$ indicating that, there is no difference between those who factor price when purchasing a cosmetic product and those who don't. It can be added that, consumers do not consider the price of cosmetic products that much if it will serve the purpose they want it to from information gathered through advertising and from others view.

Brand choice interestingly, is negatively related to the amount spent on cosmetic products. Those who considers brand spend Rs. 118.13 less. The coefficient of this variable is statistically insignificant at 5\% indicating that, there is no difference on how much is spent on cosmetic products between those who consider a brand of a cosmetic product and those who don't.

All these variables, as shown, have a role to play in the purchase of cosmetic products. They are $20 \%$ responsible for the variations in the amount of money spent on them and with an F value of 7.43 , all the slope coefficients are statistically significant at 5\%. This indicates that, though one might not consider the brand of a product as well as how much is charged on the product, one will be influenced by them together with the adverts seen on them and the advice from others on a product. It can be added that, one will spend on a product if others tell him or her of its quality. This can be seen from our survey that, $99 \%$ of the respondents go out for the best products that address their needs and wouldn't worry about the brand or the high cost on the product.

This last model is chosen because it explained the problem better. The variation in income was reduced by taking its natural log and this made the income or pocket money of the respondents statistically significant. Also, most of the variables considered in the regression are significant with a higher $\mathrm{R}^{2}$.

\subsection{Recommendations and Conclusion}

It can be seen from the study that, on average, advertising does have influence on the purchase of cosmetic products and it is a must for cosmetic firms to continue advertising on their products if they require maximum sales. Also, we found out that, though advertising does influence the purchase of consumers, other factors like income and others' recommendation do play a role in one's purchase.

In our study, we had wanted to estimate the effect of advertising on firms' sales as well, but no access to data was the reason why this was not achieved.

Again, we were constraint by time and the resources at our disposal. We will suggest to others to increase the sample size and the study area to know the effect of advertising on consumers' buying behaviour.

From the study, the following recommendations were suggested.

i.) Advertising works and affects consumers' purchase in the long run. It is required of firms to increase their advertising budget and make advertising lively for consumers to associate with. This will definitely have an impact on the sales of cosmetic firms. Advertising in the long run tend to make demand for cosmetic goods inelastic and this according to Robinson (1933) and Chamberlin (1933) will persuade consumers to be attached to a particular brand.

ii.) The complementary view of advertising was found not to be so strong for cosmetic products. The respondents stated that, the prestige attached to a brand was not all they look out for when purchasing a product. With as high as $40 \%$ of respondents stating this as a weak reason for purchasing a product, it falls on cosmetic firms to concentrate on the quality which $99 \%$ of the respondents believe they look out for in a product.

iii.) With about $15 \%$ to $20 \%$ growth in the demand for cosmetic products annually, it is required of firms to pay attention to the required needs of consumers and channel this into their advertising contents. Making use of the most patronised media; television internet and prints, to increase their sales.

iv.) One thing also found in the study was that, consumers like to factor in discounted prices when purchasing cosmetic products. It is therefore required of firms to make their prices affordable for consumers.

Advertising satisfies the needs of the firm as well as the wishes of consumers. Its role can never be replaced by any other means in this dynamic world of ours. It is therefore a must for firms to strategize and know when and where they should advertise to gain maximum returns. The consumers should be considered as a factor of production, they need to be informed about products and until that is done, the products of firms will still be in 
stores with no demand for them.

\section{References}

Associated Chambers of Commerce and Industry in India, ASSOCHAM (2013), http://www.assocham.org/prels/shownewsarchive.php?id=4128

(Accessed on 13/05/14)

Bagwell K. (2001), "The economic analysis of advertising, Introduction”, American Economic Review Volume 2, 81, 224-239

Bain, Joe S. (1956), "Barriers to New Competition: Their Character and Consequences in Manufacturing Industries", Cambridge, MA: Harvard University Press.

Bin Junaid A. et al. (2013), "A Study on the Purchase Behavior and Cosmetic Consumption Pattern among Young Females in Delhi and NCR", Journal of Social and Development Sciences, Vol. 4, No. 5, pp. 205-211, May 2013 (ISSN 2221-1152)

Borden N. H (1942), “The Economic Effects of Advertising” First Edition, Richard D. Irwin, Inc.

Beauty Mart Report, (2013) http://www.beautymart.co.in/industry-scenario-india.php (Accessed on 27/05/14)

Chamberlin, E. (1933), "The Theory of Monopolistic Competition", Cambridge, MA: Harvard University Press.1948.

Cohen D.(1988), “Advertising”, Longman Higher Education

Comanor, William. S. and Thomas. A. Wilson (1967), "Advertising, Market Structure and Performance," The Review of Economics and Statistics, 49, 423-40.

Comanor, William S. and Thomas A. Wilson (1974), "Advertising and Market Power", Cambridge, MA: Harvard University Press.

Doyle P. (Nov., 1968), “Advertising Expenditure and Consumer Demand” Oxford Economic Papers, New Series, Vol. 20, No. 3 (Nov., 1968), pp. 394-416, Oxford University Press.

Ekelund, R. B., Jr. and Saurman D. S. (1988), "Advertising and the Market Process: A Modern Economic View", San Francisco, CA: Pacific Research Institute for Public Policy.

Gujrati, Damodar N. (2003),"Basic Econometrics", Mc-Graw- Hill Companies, Inc.: New York

Horsky D. and Simon L.S. (1983), “Advertising and the Diffusion of New Products”, Marketing Science, 2 (1), pp. 1-17

Krishnan V.T. and JainD.C. (2006), “Optimal Dynamic Advertising Policy for New Products" ,Management Science, 52 (12), 1957-1969

Kumar A. et al (2011) "Advertising and Consumer Buying Behaviour: A Study with special reference to Nestle ltd.”, Volume No. 2 (2011), issue No. 10 (October, 2011), International Journal of Research in Commerce \& Management.

Marshall, A. (1890), _-Principles of Economics", London: MacMillan and Co.

Marshall, A. (1919), "Industry and Trade", London: MacMillan and Co

Ozga, S. A. (1960), "Imperfect Markets Through Lack of Knowledge,” Quarterly Journal of Economics, 74.1, 29-52.

Pindyck R. S. and Rubinfield, D. L. (1995), “Microeconomics”, Prentice Hall International, Inc. pp. 395

Robinson, Joan (1933), "Economics of Imperfect Competition", London: MacMillan and Co

Sharma J, Sharma S., "Sales and Advertisement Relationship for Selected Companies Operating in India" (2009), School of Doctoral Studies (European Union) Journal July, 2009, No. 1

Sloman J. and Wride A. (2007), "Economics" Seventh Edition, Prentice Hall Financial Times

Stigler, George J. and Gary S. Becker (1977), “De Gustibus Non Est Disputandum,”American Economic Review, 67, 76-90.

Sundarsan, P.K. (2007), "Evaluating Effectiveness of Advertising on Sales; A Study Using Firm Level Data", ICFAI Journal of Managerial Economics, Vol. V (1), pp.54-62

Taylor, Lester D. and Daniel, Weiserbs (1972), "Advertising and Aggregate Consumption Function", American Economic Review, Vol. LX11 (4), pp.642-55 
APPENDIX

Frequency Tables

\begin{tabular}{|rl|r|r|r|r|}
\hline \multicolumn{7}{|c|}{ Sex of Respondents } \\
\hline & Frequency & Percent & Valid Percent & $\begin{array}{c}\text { Cumulative } \\
\text { Percent }\end{array}$ \\
\hline Valid & Female & 50 & 50.0 & 50.0 & 50.0 \\
& Male & 50 & 50.0 & 50.0 & 100.0 \\
& Total & 100 & 100.0 & 100.0 & \\
\hline
\end{tabular}

\begin{tabular}{|c|c|c|c|c|c|}
\hline \multicolumn{6}{|c|}{ Age of Respondents } \\
\hline & & Frequency & Percent & Valid Percent & $\begin{array}{c}\text { Cumulative } \\
\text { Percent }\end{array}$ \\
\hline \multirow[t]{4}{*}{ Valid } & $15-25$ & 51 & 51.0 & 51.0 & 51.0 \\
\hline & $25-35$ & 46 & 46.0 & 46.0 & 97.0 \\
\hline & $35-45$ & 3 & 3.0 & 3.0 & 100.0 \\
\hline & Total & 100 & 100.0 & 100.0 & \\
\hline
\end{tabular}

\section{Marital Status of Respondents}

\begin{tabular}{|ll|r|r|r|r|}
\hline & & & & \multicolumn{2}{c|}{$\begin{array}{c}\text { Cumulative } \\
\text { Percent }\end{array}$} \\
\hline Valid & Single & 69 & 69.0 & 69.0 & 69.0 \\
& Married & 31 & 31.0 & 31.0 & 100.0 \\
& Total & 100 & 100.0 & 100.0 & \\
\hline
\end{tabular}

Occupation of Respondents

\begin{tabular}{|ll|r|r|r|r|}
\hline & Frequency & Percent & Valid Percent & \multicolumn{2}{c|}{$\begin{array}{c}\text { Pumulative } \\
\text { Percent }\end{array}$} \\
\hline Valid & Student & 50 & 50.0 & 50.0 & 50.0 \\
& Banking & 6 & 6.0 & 6.0 & 56.0 \\
Teaching & 3 & 3.0 & 3.0 & 59.0 \\
Marketing & 10 & 10.0 & 10.0 & 69.0 \\
IT and Computer & 9 & 9.0 & 9.0 & 78.0 \\
Other & 22 & 22.0 & 22.0 & 100.0 \\
Total & 100 & 100.0 & 100.0 & \\
\hline
\end{tabular}




\begin{tabular}{|c|c|c|c|c|c|}
\hline \multicolumn{6}{|c|}{ Brand of Cosmetic Products } \\
\hline & & Frequency & Percent & Valid Percent & $\begin{array}{c}\text { Cumulative } \\
\text { Percent }\end{array}$ \\
\hline \multirow[t]{8}{*}{ Valid } & HUL & 39 & 39.0 & 39.0 & 39.0 \\
\hline & Emami & 8 & 8.0 & 8.0 & 47.0 \\
\hline & Revlon & 3 & 3.0 & 3.0 & 50.0 \\
\hline & L'Oreal & 11 & 11.0 & 11.0 & 61.0 \\
\hline & Nivea & 17 & 17.0 & 17.0 & 78.0 \\
\hline & Garnier & 20 & 20.0 & 20.0 & 98.0 \\
\hline & Other & 2 & 2.0 & 2.0 & 100.0 \\
\hline & Total & 100 & 100.0 & 100.0 & \\
\hline
\end{tabular}

Ad_Effect

\begin{tabular}{|c|c|c|c|c|c|}
\hline & & Frequency & Percent & Valid Percent & Cumulative Percent \\
\hline \multirow[t]{3}{*}{ Valid } & No & 30 & 30.0 & 30.0 & 30.0 \\
\hline & Yes & 70 & 70.0 & 70.0 & 100.0 \\
\hline & Total & 100 & 100.0 & 100.0 & \\
\hline
\end{tabular}

Medium of Encountering Advertising

\begin{tabular}{|rl|r|r|r|r|}
\hline & & & & \multicolumn{2}{|c|}{$\begin{array}{c}\text { Cumulative } \\
\text { Percent }\end{array}$} \\
\hline Valid & Frequency & Percent & Valid Percent & 30.0 \\
& 30 & 30.0 & 30.0 & 78.0 \\
& $4 . \mathrm{V}$ & 48.0 & 48.0 & 86.0 \\
Papers & 8 & 8.0 & 8.0 & 100.0 \\
Internet & 14 & 14.0 & 14.0 & \\
Total & 100 & 100.0 & 100.0 & \\
\hline
\end{tabular}




\section{Place of Purchase}

\begin{tabular}{|c|c|c|c|c|c|}
\hline & & Frequency & Percent & Valid Percent & $\begin{array}{c}\text { Cumulative } \\
\text { Percent }\end{array}$ \\
\hline \multirow[t]{6}{*}{ Valid } & Malls & 33 & 33.0 & 33.0 & 33.0 \\
\hline & Internet & 9 & 9.0 & 9.0 & 42.0 \\
\hline & Supermarket & 42 & 42.0 & 42.0 & 84.0 \\
\hline & Pharmacy & 13 & 13.0 & 13.0 & 97.0 \\
\hline & Local Shop & 3 & 3.0 & 3.0 & 100.0 \\
\hline & Total & 100 & 100.0 & 100.0 & \\
\hline
\end{tabular}

\section{Purpose of Adverts}

\begin{tabular}{|ll|r|r|r|r|}
\hline & & & & \multicolumn{2}{c|}{$\begin{array}{c}\text { Cumulative } \\
\text { Percent }\end{array}$} \\
\hline Valid & Inform of Product & 58 & 58.0 & 58.6 & 58.6 \\
& Create perception & 19 & 19.0 & 19.2 & 77.8 \\
& Create Preference & 11 & 11.0 & 11.1 & 88.9 \\
& Create awareness & 11 & 11.0 & 11.1 & 100.0 \\
& Total & 99 & 99.0 & 100.0 & \\
Missing & System & 1 & 1.0 & & \\
Total & & 100 & 100.0 & & \\
\hline
\end{tabular}

Advertising Influence

\begin{tabular}{|c|c|c|c|c|c|}
\hline & & Frequency & Percent & Valid Percent & Cumulative Percent \\
\hline \multirow[t]{4}{*}{ Valid } & Strong & 26 & 26.0 & 26.0 & 26.0 \\
\hline & Moderate & 55 & 55.0 & 55.0 & 81.0 \\
\hline & Weak & 19 & 19.0 & 19.0 & 100.0 \\
\hline & Total & 100 & 100.0 & 100.0 & \\
\hline
\end{tabular}

\begin{tabular}{|c|c|c|c|c|c|}
\hline & & Frequency & Percent & Valid Percent & Cumulative Percent \\
\hline \multirow[t]{4}{*}{ Valid } & strong & 63 & 63.0 & 63.0 & 63.0 \\
\hline & Moderate & 32 & 32.0 & 32.0 & 95.0 \\
\hline & Weak & 5 & 5.0 & 5.0 & 100.0 \\
\hline & Total & 100 & 100.0 & 100.0 & \\
\hline
\end{tabular}


Price

\begin{tabular}{|rl|r|r|r|r|}
\hline & Frequency & Percent & Valid Percent & Cumulative Percent \\
\hline Valid & Strong & 50 & 50.0 & 50.0 & 50.0 \\
& Moderate & 38 & 38.0 & 38.0 & 88.0 \\
& 12 & 12.0 & 12.0 & 100.0 \\
Weak & 100 & 100.0 & 100.0 & \\
\hline
\end{tabular}

Others_recommendation

\begin{tabular}{|c|c|c|c|c|c|}
\hline & & Frequency & Percent & Valid Percent & Cumulative Percent \\
\hline \multirow[t]{4}{*}{ Valid } & Strong & 26 & 26.0 & 26.0 & 26.0 \\
\hline & Moderate & 52 & 52.0 & 52.0 & 78.0 \\
\hline & Weak & 22 & 22.0 & 22.0 & 100.0 \\
\hline & Total & 100 & 100.0 & 100.0 & \\
\hline
\end{tabular}

\section{Quality of Product}

\begin{tabular}{|c|c|c|c|c|c|}
\hline & & Frequency & Percent & Valid Percent & Cumulative Percent \\
\hline \multirow[t]{4}{*}{ Valid } & Strong & 71 & 71.0 & 71.0 & 71.0 \\
\hline & Moderate & 28 & 28.0 & 28.0 & 99.0 \\
\hline & Weak & 1 & 1.0 & 1.0 & 100.0 \\
\hline & Total & 100 & 100.0 & 100.0 & \\
\hline
\end{tabular}

\section{Prestige attached to Product}

\begin{tabular}{|rl|r|r|r|r|}
\hline & Frequency & Percent & Valid Percent & Cumulative Percent \\
\hline Valid & Strong & 22 & 22.0 & 22.0 & 22.0 \\
& 38 & 38.0 & 38.0 & 60.0 \\
& Moderate & 40 & 40.0 & 40.0 & 100.0 \\
Weak & 100 & 100.0 & 100.0 & \\
Total & & & \\
\hline
\end{tabular}




\begin{tabular}{|c|c|c|c|c|c|}
\hline \multicolumn{6}{|c|}{ Packaging of Product } \\
\hline & & Frequency & Percent & Valid Percent & Cumulative Percent \\
\hline \multirow[t]{4}{*}{ Valid } & Strong & 25 & 25.0 & 25.0 & 25.0 \\
\hline & Moderate & 43 & 43.0 & 43.0 & 68.0 \\
\hline & Weak & 32 & 32.0 & 32.0 & 100.0 \\
\hline & Total & 100 & 100.0 & 100.0 & \\
\hline
\end{tabular}

Being_Beautiful

\begin{tabular}{|c|c|c|c|c|c|}
\hline & & Frequency & Percent & Valid Percent & $\begin{array}{c}\text { Cumulative } \\
\text { Percent }\end{array}$ \\
\hline \multirow[t]{4}{*}{ Valid } & Strong & 42 & 42.0 & 42.0 & 42.0 \\
\hline & Moderate & 44 & 44.0 & 44.0 & 86.0 \\
\hline & Weak & 14 & 14.0 & 14.0 & 100.0 \\
\hline & Total & 100 & 100.0 & 100.0 & \\
\hline
\end{tabular}

\begin{tabular}{|c|c|c|c|c|c|}
\hline & & Frequency & Percent & Valid Percent & Cumulative Percent \\
\hline \multirow[t]{4}{*}{ Valid } & Strong & 9 & 9.0 & 9.0 & 9.0 \\
\hline & Moderate & 42 & 42.0 & 42.0 & 51.0 \\
\hline & Weak & 49 & 49.0 & 49.0 & 100.0 \\
\hline & Total & 100 & 100.0 & 100.0 & \\
\hline
\end{tabular}

Being Socially Acceptable

\begin{tabular}{|rl|r|r|r|r|}
\hline & Frequency & Percent & Valid Percent & Cumulative Percent \\
\hline Valid & Strong & 39 & 39.0 & 39.0 & 39.0 \\
& Moderate & 41 & 41.0 & 41.0 & 80.0 \\
& 20 & 20.0 & 20.0 & 100.0 \\
Weak & 100 & 100.0 & 100.0 & \\
Total & & & & \\
\hline
\end{tabular}




\begin{tabular}{|c|c|c|c|c|c|c|c|}
\hline & \multicolumn{3}{|c|}{ Sex } & \multicolumn{4}{|c|}{ Age } \\
\hline & Male & Female & Total & \begin{tabular}{|l|}
$15-25$ \\
years
\end{tabular} & \begin{tabular}{|l|}
$25-35$ \\
years
\end{tabular} & \begin{tabular}{|l|}
$35-45$ \\
years
\end{tabular} & Total \\
\hline $\begin{array}{l}\text { Total } \\
\text { Surveyed }\end{array}$ & 50 & 50 & 100 & 51 & 46 & 3 & \\
\hline HUL & $11 \%$ & $28 \%$ & $39 \%$ & $22 \%$ & $17 \%$ & & $39 \%$ \\
\hline Emami & $7 \%$ & $1 \%$ & $8 \%$ & $0 \%$ & $8 \%$ & & $8 \%$ \\
\hline Revlon & $1 \%$ & $2 \%$ & $3 \%$ & $1 \%$ & $2 \%$ & & $3 \%$ \\
\hline L'Oreal & $3 \%$ & $8 \%$ & $11 \%$ & $8 \%$ & $2 \%$ & $1 \%$ & $11 \%$ \\
\hline Nivea & $11 \%$ & $6 \%$ & $17 \%$ & $8 \%$ & $9 \%$ & & $17 \%$ \\
\hline Garnier & $16 \%$ & $4 \%$ & $20 \%$ & $11 \%$ & $7 \%$ & $2 \%$ & $20 \%$ \\
\hline Oriflame & $1 \%$ & $1 \%$ & $2 \%$ & $1 \%$ & $1 \%$ & & $2 \%$ \\
\hline
\end{tabular}

\section{Oriflame}

Satisfied with the Product

\begin{tabular}{|c|c|c|c|c|c|}
\hline & & Frequency & Percent & Valid Percent & Cumulative Percent \\
\hline \multirow[t]{3}{*}{ Valid } & 0 & 11 & 11.0 & 11.0 & 11.0 \\
\hline & Yes & 89 & 89.0 & 89.0 & 100.0 \\
\hline & Total & 100 & 100.0 & 100.0 & \\
\hline
\end{tabular}

\section{Cross Tabulations}

Age, Sex and Brand Cross tabulation

Ad_Effect * Consumer's Satisfaction of ProductCrosstabulation

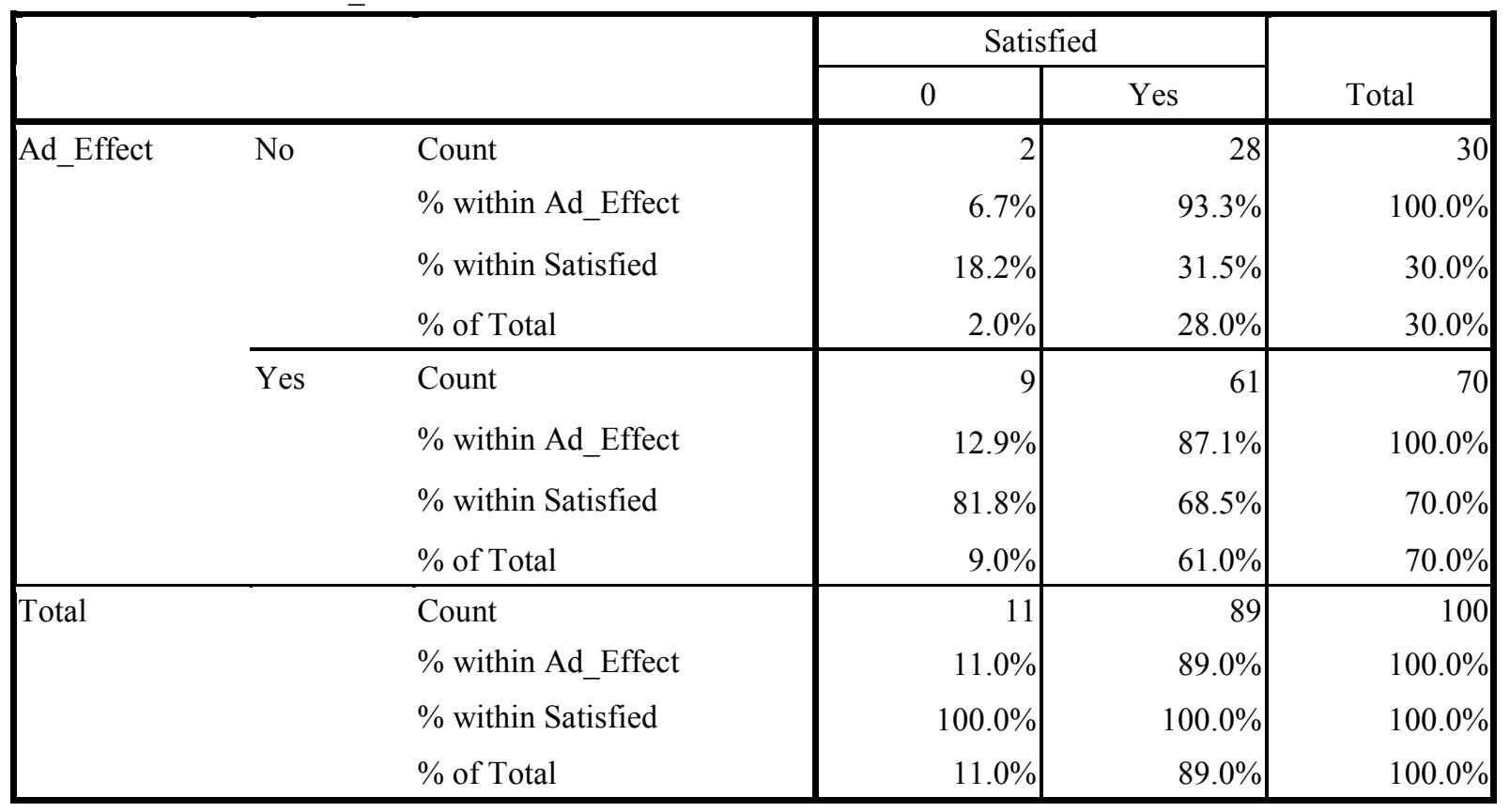


Ad_Effect * Brand_of_CosCrosstabulation

\begin{tabular}{|c|c|c|c|c|c|c|c|c|c|}
\hline & & \multicolumn{7}{|c|}{ Brand_of_Cos } & \multirow[t]{2}{*}{ Total } \\
\hline & & HUL & Emami & Revlon & L'Oreal & Nivea & Garnier & Other & \\
\hline \multirow[t]{8}{*}{ Ad_Effect No } & Count & 10 & 2 & 1 & 5 & 6 & 5 & 1 & 30 \\
\hline & $\begin{array}{l}\% \text { within } \\
\text { Ad_Effect }\end{array}$ & $33.3 \%$ & $6.7 \%$ & $3.3 \%$ & $16.7 \%$ & $20.0 \%$ & $16.7 \%$ & $3.3 \%$ & $100.0 \%$ \\
\hline & $\begin{array}{l}\% \text { within } \\
\text { Brand_of_Cos }\end{array}$ & $25.6 \%$ & $25.0 \%$ & $33.3 \%$ & $45.5 \%$ & $35.3 \%$ & $25.0 \%$ & $50.0 \%$ & $30.0 \%$ \\
\hline & $\%$ of Total & $10.0 \%$ & $2.0 \%$ & $1.0 \%$ & $5.0 \%$ & $6.0 \%$ & $5.0 \%$ & $1.0 \%$ & $30.0 \%$ \\
\hline & Count & 29 & 6 & 2 & 6 & 11 & 15 & 1 & 70 \\
\hline & $\begin{array}{l}\text { \% within } \\
\text { Ad_Effect }\end{array}$ & $41.4 \%$ & $8.6 \%$ & $2.9 \%$ & $8.6 \%$ & $15.7 \%$ & $21.4 \%$ & $1.4 \%$ & $100.0 \%$ \\
\hline & $\begin{array}{l}\% \text { within } \\
\text { Brand_of_Cos }\end{array}$ & $74.4 \%$ & $75.0 \%$ & $66.7 \%$ & $54.5 \%$ & $64.7 \%$ & $75.0 \%$ & $50.0 \%$ & $70.0 \%$ \\
\hline & $\%$ of Total & $29.0 \%$ & $6.0 \%$ & $2.0 \%$ & $6.0 \%$ & $11.0 \%$ & $15.0 \%$ & $1.0 \%$ & $70.0 \%$ \\
\hline \multirow[t]{4}{*}{ Total } & Count & 39 & 8 & 3 & 11 & 17 & 20 & 2 & 100 \\
\hline & $\begin{array}{l}\% \text { within } \\
\text { Ad_Effect }\end{array}$ & $39.0 \%$ & $8.0 \%$ & $3.0 \%$ & $11.0 \%$ & $17.0 \%$ & $20.0 \%$ & $2.0 \%$ & $100.0 \%$ \\
\hline & $\begin{array}{l}\% \text { within } \\
\text { Brand_of_Cos }\end{array}$ & $100.0 \%$ & $100.0 \%$ & $100.0 \%$ & $100.0 \%$ & $100.0 \%$ & $100.0 \%$ & $100.0 \%$ & $100.0 \%$ \\
\hline & $\%$ of Total & $39.0 \%$ & $8.0 \%$ & $3.0 \%$ & $11.0 \%$ & $17.0 \%$ & $20.0 \%$ & $2.0 \%$ & $100.0 \%$ \\
\hline
\end{tabular}

Ad_Effect * Sex Crosstabulation

\begin{tabular}{|c|c|c|c|c|c|}
\hline & & & \multicolumn{2}{|c|}{ Sex } & \multirow[b]{2}{*}{ Total } \\
\hline & & & Female & Male & \\
\hline \multirow[t]{8}{*}{ Ad_Effect } & No & Count & 15 & 15 & 30 \\
\hline & & $\%$ within Ad_Effect & $50.0 \%$ & $50.0 \%$ & $100.0 \%$ \\
\hline & & $\%$ within Sex & $30.0 \%$ & $30.0 \%$ & $30.0 \%$ \\
\hline & & $\%$ of Total & $15.0 \%$ & $15.0 \%$ & $30.0 \%$ \\
\hline & Yes & Count & 35 & 35 & 70 \\
\hline & & $\%$ within Ad_Effect & $50.0 \%$ & $50.0 \%$ & $100.0 \%$ \\
\hline & & \% within Sex & $70.0 \%$ & $70.0 \%$ & $70.0 \%$ \\
\hline & & $\%$ of Total & $35.0 \%$ & $35.0 \%$ & $70.0 \%$ \\
\hline \multirow[t]{4}{*}{ Total } & & Count & 50 & 50 & 100 \\
\hline & & $\%$ within Ad_Effect & $50.0 \%$ & $50.0 \%$ & $100.0 \%$ \\
\hline & & $\%$ within Sex & $100.0 \%$ & $100.0 \%$ & $100.0 \%$ \\
\hline & & $\%$ of Total & $50.0 \%$ & $50.0 \%$ & $100.0 \%$ \\
\hline
\end{tabular}




\begin{tabular}{|c|c|c|c|c|c|c|c|c|c|c|}
\hline \multirow{2}{*}{$\begin{array}{l}\text { Dep. } \\
\text { Variable }\end{array}$} & \multirow{2}{*}{$\begin{array}{l}\text { Intercept } \\
\text { (t value) }\end{array}$} & \multicolumn{6}{|c|}{ Independent Variables } & \multirow{2}{*}{$\begin{array}{l}\mathrm{R}^{2} \\
\text { (Adj) }\end{array}$} & \multirow[t]{2}{*}{$\mathrm{F}$} & \multirow[t]{2}{*}{$\mathrm{P}$} \\
\hline & & $\begin{array}{l}\text { Income } \\
\text { (t value) }\end{array}$ & $\begin{array}{l}\text { ln_Income } \\
\text { (t value) }\end{array}$ & $\begin{array}{l}\mathrm{Da} \\
\text { (t value) }\end{array}$ & $\begin{array}{l}\mathrm{Db} \\
\text { ( } \mathrm{t} \text { value) }\end{array}$ & $\begin{array}{l}\mathrm{Dp} \\
(\mathrm{t} \\
\text { value })\end{array}$ & $\begin{array}{l}\begin{array}{l}\mathrm{Dr} \\
(\mathrm{t}\end{array} \\
\text { value })\end{array}$ & & & \\
\hline Exp & $\begin{array}{l}306.0627 \\
(2.80)\end{array}$ & $\begin{array}{l}.0036 \\
(1.38)\end{array}$ & & $\begin{array}{l}396.49 \\
(3.37)^{*}\end{array}$ & & & & $\begin{array}{l}0.13 \\
(0.11)\end{array}$ & 7.26 & 0.00 \\
\hline Ln_Exp & $\begin{array}{l}4.5221 \\
(7.19) \\
\end{array}$ & & $\begin{array}{l}.1267 \\
(1.87) \\
\end{array}$ & $\begin{array}{l}.7151 \\
(3.84)^{*}\end{array}$ & & & & $\begin{array}{l}0.16 \\
(0.15)\end{array}$ & 9.62 & 0.00 \\
\hline Ln_Exp & $\begin{array}{l}4.5221 \\
(7.95)\end{array}$ & & $\begin{array}{l}.1267 \\
(1.98)^{*}\end{array}$ & $\begin{array}{l}.7151 \\
(3.92)^{*}\end{array}$ & & & & 0.16 & 12.59 & 0.00 \\
\hline $\operatorname{Exp}$ & $\begin{array}{l}58.5737 \\
(0.42) \\
\end{array}$ & $\begin{array}{l}.0036 \\
(1.67) \\
\end{array}$ & & $\begin{array}{l}410.45 \\
(4.48)^{*}\end{array}$ & $\begin{array}{l}-154.31 \\
(-1.55) \\
\end{array}$ & $\begin{array}{l}213.84 \\
(1.81)\end{array}$ & $\begin{array}{l}251.33 \\
(2.49)^{*}\end{array}$ & 0.19 & 7.40 & 0.00 \\
\hline $\operatorname{Exp}$ & $\begin{array}{l}-592.24 \\
(-1.58) \\
\end{array}$ & & $\begin{array}{l}77.1233 \\
(2.01) *\end{array}$ & $\begin{array}{l}409.73 \\
(4.97) *\end{array}$ & $\begin{array}{l}-118.13 \\
(-1.06) \\
\end{array}$ & $\begin{array}{l}205.54 \\
(1.80)\end{array}$ & $\begin{array}{l}224.19 \\
(2.16)^{*}\end{array}$ & 0.20 & 7.43 & $\mathbf{0 . 0 0}$ \\
\hline $\operatorname{Exp}$ & $\begin{array}{l}-592.24 \\
(-1.58)\end{array}$ & & $\begin{array}{l}77.1233 \\
(2.01) *\end{array}$ & $\begin{array}{l}409.73 \\
(4.97) *\end{array}$ & $\begin{array}{l}-118.13 \\
(-1.06)\end{array}$ & $\begin{array}{l}205.54 \\
(1.80) \\
\end{array}$ & $\begin{array}{l}224.19 \\
(2.16) *\end{array}$ & 0.20 & 7.43 & $\mathbf{0 . 0 0}$ \\
\hline ln_Exp & $\begin{array}{l}4.42 \\
(6.48)^{*}\end{array}$ & & $\begin{array}{l}0.1081 \\
(1.66)\end{array}$ & $\begin{array}{l}.7490 \\
(3.97)^{*}\end{array}$ & $\begin{array}{l}-0.3577 \\
(-1.45)\end{array}$ & $\begin{array}{l}0.4305 \\
(1.77)\end{array}$ & $\begin{array}{l}.2617 \\
(1.60)\end{array}$ & 0.22 & 6.18 & 0.00 \\
\hline
\end{tabular}

Regression Models

Italicised indicates a robust regression, meant to correct heteroskedasticity

*indicates statistically significant values

\section{INSTITUTE FOR SOCIAL AND ECONOMIC CHANGE, \\ BANGALORE}

QUESTIONNAIRE FOR USERS OF COSMETIC PRODUCTS

This research is to find out the effects of advertising on buying behaviour of consumers of cosmetic products. All information provided would be confidential. Please tick the box and write where appropriate.

SECTION A: Biographical details

1. Gender

Male $\square \quad$ Female $\square$

2. Age range
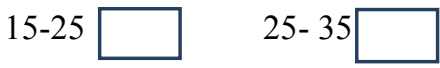

35- 45

45- 55

55-above

3. Marital Status

Single

Married

4. Occupation

Student

Banking

Teaching

Marketing

IT and Computer

Other.

5. What is your monthly income/ Pocket money Rs

\section{SECTION B:}

6. Which brand of cosmetics do you use among these?

Lakme (Hindustan Unilever Ltd)

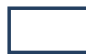

Emami

Garnier

Revlon

L'Oreal

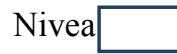

Other.

7. Does advertising influence your purchase of the cosmetic product above?

Yes

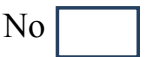

8. If yes, which medium of advertising influences your purchase of the above cosmetic product?

Television Print (Newspapers, Magazines, Brochures) Internet (Online) 
9. Where do you most purchase the above cosmetic product brand?

\begin{tabular}{|c|c|c|c|}
\hline Malls & Internet(online) & Supermarket] & Pharmacy \\
\hline
\end{tabular}

10. What purpose do adverts on the cosmetic product serve you?

Inform you of the features and benefits of the product

Create the desired perceptions of the product

Create a preference for the product

Create awareness of a new product

11. How much do you spend on the cosmetic products monthly? Rs.

12. Rankthefactors which most influence your purchase ofthecosmetic products

\begin{tabular}{|l|l|l|l|}
\hline & Strong Influence & $\begin{array}{l}\text { Moderate } \\
\text { Influence }\end{array}$ & Weak Influence \\
\hline Advertising & & & \\
\hline Brand & & & \\
\hline Price & & & \\
\hline Recommendation from others & & & \\
\hline Quality & & & \\
\hline Prestige & & & \\
\hline Packaging & & & \\
\hline Other(................ & & & \\
\hline
\end{tabular}

13. Why do you purchase the cosmetic products?

\begin{tabular}{|l|l|l|l|}
\hline & Strong Reason & Moderate Reason & Weak Reason \\
\hline To look beautiful & & & \\
\hline To be attracted to the opposite sex & & & \\
\hline To be socially acceptable & & & \\
\hline & & & \\
Other.................... & & & \\
\hline
\end{tabular}

14. Are you satisfied using the product? Yes

No.

If Yes/No, Why

Please add your comments.

THANK YOU.

Online survey

https://docs.google.com/forms/d/1Isear1MMlOMgCgHsDJrtZhS7WuIH9xngIBbLEcASo_g/viewform 
The IISTE is a pioneer in the Open-Access hosting service and academic event management. The aim of the firm is Accelerating Global Knowledge Sharing.

More information about the firm can be found on the homepage:

http://www.iiste.org

\section{CALL FOR JOURNAL PAPERS}

There are more than 30 peer-reviewed academic journals hosted under the hosting platform.

Prospective authors of journals can find the submission instruction on the following page: http://www.iiste.org/journals/ All the journals articles are available online to the readers all over the world without financial, legal, or technical barriers other than those inseparable from gaining access to the internet itself. Paper version of the journals is also available upon request of readers and authors.

\section{MORE RESOURCES}

Book publication information: http://www.iiste.org/book/

\section{IISTE Knowledge Sharing Partners}

EBSCO, Index Copernicus, Ulrich's Periodicals Directory, JournalTOCS, PKP Open Archives Harvester, Bielefeld Academic Search Engine, Elektronische Zeitschriftenbibliothek EZB, Open J-Gate, OCLC WorldCat, Universe Digtial Library, NewJour, Google Scholar

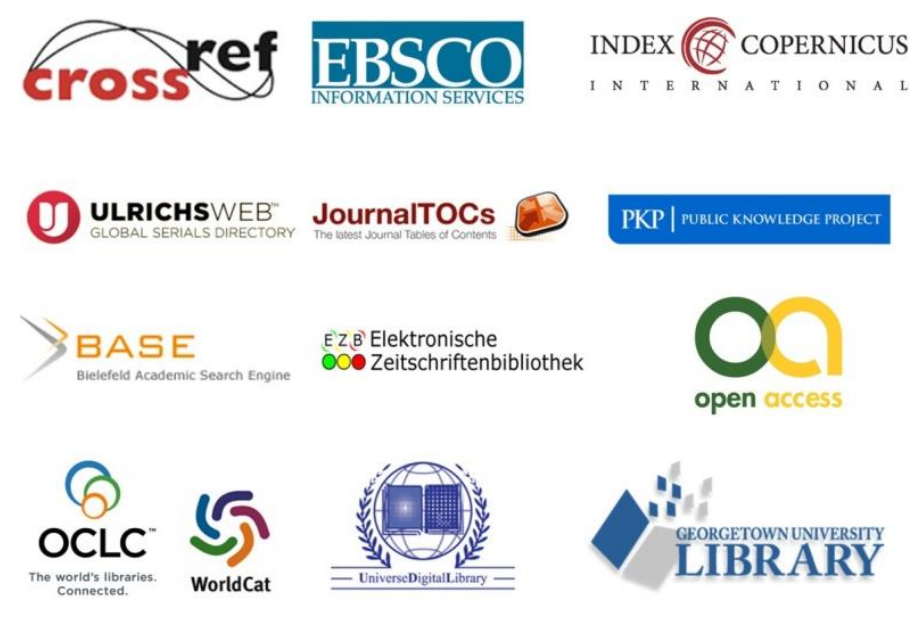

